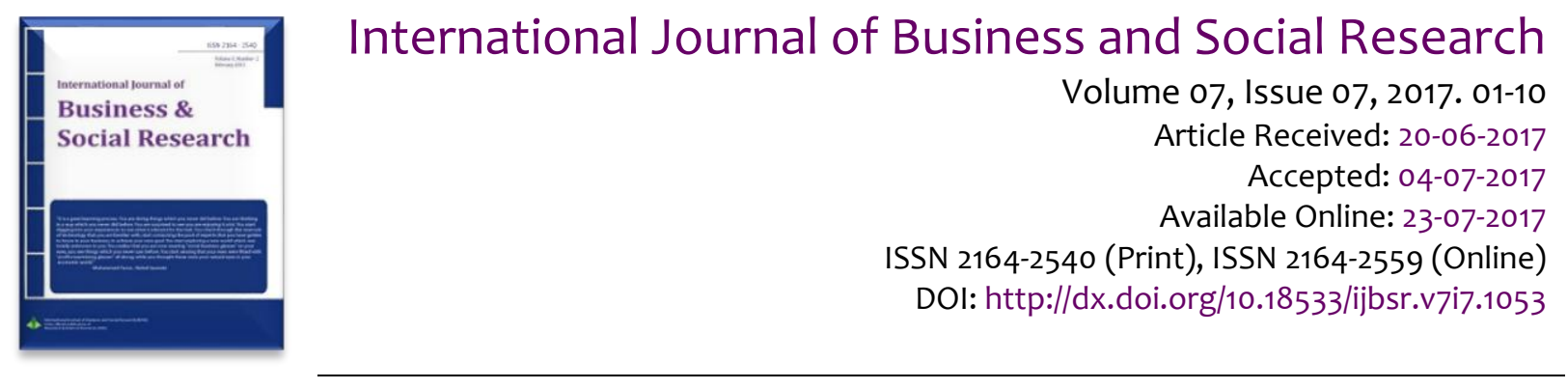

\title{
Modelling of IPO Underpricing in Bangladesh
}

\author{
Faysal Ahmad Khan', Tasruma Sharmeen Chowdhury²
}

\begin{abstract}
This study shows the degree of underpricing in initial public offering in Bangladesh and the relationship of underpricing with some company specific and issue specific variables. To measure the degree of underpricing both initial return (IR) and market adjusted initial returns (MAIR) have been used. The study reveals $284 \%$ average initial return and $266 \%$ average market adjusted return for the first listing day of the IPOs for the period 2007 to 2016. Regression analysis is used to find the relationship between various predictor variables and underpricing. The regression analysis depicts that issue price, oversubscription, market return and size of the firm have significant effect on initial return. Similarly, market adjusted initial return is also influenced by issue price, oversubscription and size of the firm have significant effect over. The study found that issue size, age of the firm, floating percentage of share has very little relationship with underpricing in Bangladesh.
\end{abstract}

Keywords: Bangladesh, Initial public offering, Initial return (IR), Market adjusted initial return (MAIR), Underpricing. JEL Codes: G3, G12, G30.

This is an open access article under Creative Commons Attribution 4.0 License, 2017.

\section{Introduction}

Underpricing of Initial public offerings (IPO) is important for the investors who want to invest in primary market to gain a substantial profit. IPO provides the investor an opportunity to participate in the firm's growth by investing funds in the company. In Bangladesh almost all IPOs are oversubscribed, which signals high demand of IPOs among investors. This high demand is created as there is a high chance to earn abnormal return on the first trading day. This chance increases when offer price of an IPO is remarkably less than the first trading price. This phenomenon is referred as IPO underpricing. Companies raise fund through IPO and use it for expansion. Though IPO underpricing causes loss of capital for the issuing company, it leaves some money on the table to attract investors. However; issuers have potential to make gains in the secondary market, when the value of the stocks increases. This higher value of stocks in secondary market compensates the loss of issuers and acts as incentives to go public with less offer price.

Pragmatic proves express existence of positive abnormal return of IPOs on first listing day in different counties (Loughran and Ritter, 2004; Sohail and Raheman , 2009; Yaakob and Halim, 2016; Chan, Wang,

\footnotetext{
${ }^{1}$ Lecturer, Bangladesh Institute of Capital Market, E-mail: faysal.bicm@gmail.com

${ }^{2}$ Lecturer, Bangladesh Institute of Capital Market, E-mail: tasruma.bicm@gmail.com
} 
and Wei, 2004; Shah and Mehta, 2015). In Bangladesh Islam (1999) found 116.01\% average initial returns of IPOs. Subsequently, Islam, Ali and Ahmed (2010) documented the mean level of underpricing of 117 companies as $156.16 \%$. The reasons behind this high level of underpricing in this country is needed to be explored. Literatures of different countries depicted effect of offer price, offer size, size of the firm, oversubscription rate, free float on degree of underpricing of IPOs. However, security market size, the efficiency of securities markets, regulatory framework, and the behavior of IPO investors in developing countries differ from those of developed countries. The reasons to effect IPO underpricing may differ in Bangladesh as every country has different regulatory framework, investors' perception and expectations, market size etc. Islam, Ali and Ahmed (2010) found positive effect of offer size and firm size on degree of underpricing. But in previous studies in Bangladesh, significant indication for the investors to predict the level of abnormal return they will get from an IPO were not found. The focus of this study is to explore the factors affecting IPO underpricing in Bangladesh and identify the most important factors to aid the investors to look into the factors before making investment decision. This research also formulate model that will provide implication to investors to predict the level of underpricing likely to take place in an upcoming IPO.

This study tries to find the degree of underpricing in Dhaka Stock Exchange by examining 100 issues that were listed in Dhaka Stock exchange (DSE) from 2007 to 2016. Bangladesh Securities and Exchange Commission introduced Public Issue Rule, 2015 replacing Public Issue Rules, 2006. As per the new rule, No premium can be charged under fixed price method. This study also included the IPOs after enactment of the new rule. The research also attempts to formulate a model for predicting degree of IPO underpricing in DSE considering significant independent variables suggested by statistical tools.

The structure of the remainder of this paper is as follows. First, literatures have been reviewed to present empirical evidence of existence of IPO underpricing scenario in different countries and the factors behind those underpricing. Then, source of data for this study as well as the methodology of the study have been discussed. After that, the results of the research have been documented with interpretations. Then in the final part, the main findings have been summarized with some concluding remarks.

\section{Literature review}

IPO underpricing refers to the positive return investors can gain on the very first day of trading of a new issue. The existence of underpricing of IPOs in different countries has been proven by many previous studies.

Loughran and Ritter (2004) conducted research on 6,391 IPOs of United States from 1980-2003. They concluded that degree of underpricing changes over time. The average first day return of 1,982 new issues over 1980-1989 was 7.3\%.A rise in the average first day return of IPOs was observed in the period of 1990 to 1998. During this stipulated period, it was $14.8 \%$. The market witnessed a very sharp rise in the average first day return of IPOs in 1999-2000. It became 65\%. After the bubble burst it reduced to11.7\% with reduced number of IPOs in the period of 2001-2003.

Islam, Ali, and Ahmad (2010) presented summarized tables of average returns of new issues in major stock markets of the world. The minimum average initial return of IPOs was discovered in France. As cited by Islam et al., (2010), over the period 1983-1992, average initial return of 187 IPOs was found as 4.2\%.Other six countries outside Asia provided less than $10 \%$ average initial returns in new issues. Average initial returns for Israel (1993-1994), Canada (1971-1992), Denmark (1984-1998), Austria (1984-1999), Chile (1982-1997) and Finland were listed respectively as 4.5\%, 5.4\%, 6.4\%, 6.5\%, 8.8\% and 9.6\%. Among 23 countries 14 countries provided $10 \%-50 \%$ underpricing of IPOs. More than $50 \%$ average initial returns of IPOs were found in Research considering 62 IPOs of Portugal in the time period of 1986 to 1987 found $54.4 \%$ average initial return. In Brazil average initial return of 62 IPOs over 1979-1990 was 78.5\%.

Chan, Wang, and Wei (2004) investigated IPOs of China over the period 1993-1998 and found 178\% average initial return for ordinary domestic shares' IPOs. Sohail and Raheman (2009) studied 50 IPOs 
listed on Karachi Stock Exchange from the period 2000 to 2006.The research found the average underpricing of IPOs was 35.66\% in Pakistan. In Malaysia, mean first day return of companies listed in 2015 was found as 12.81\% (Yaakob and Halim, 2016). In India Shah and Mehta (2015) found average gain in new issues as $7.19 \%$.

Some studied tried to find out the factors behind IPO underpricing. This study considered some determinants which are supported by different literatures. The factors considered in this study are: offer size, size of the firm, rate of oversubscription and free float.

In their attempt to identify the determinants of IPOs initial return, Bansal and Khanna (2012) analyzed effect of number of share offered, issue size, market capitalization, firm's age and etc on degree of underpricing. No significant effect of firms age was found. The multiple-regression model revealed negative relationship between issue size and market adjusted abnormal return. That means, underpricing is less when the issue size is higher. This result is consistent with the discussion by Beatty \& Ritter (1986). Beatty and Ritter (1986) considered inverse of proceeds to be raised by public offering as a proxy of uncertainty and explained small size creates more uncertainty that leads to higher underpricing. Titman and Wessels (1988) discussed that the cost of issuing new equity was higher in case of small firms as uncertainty was higher. Kiymaz (2000) considered size of issuer as an explanatory variable for underpricing of new issues. Acqua, Etro, Teti, and Murri (2014) found negative relationship between size of the firm and degree of IPO underpricing. Increase in firm size reduces risk and uncertainty. Hence degree of IPO underpricing is also reduced.

In a study based on 113 new issues in India, Shah and Mehta (2015) investigated influence of issue price, issue size, oversubscription of IPO, market Index return on listing day return of new issues over 20102014. According to them, subscribers of new issues were gaining $7.19 \%$ market adjusted abnormal returns on an average. They concluded that, there is positive impact of oversubscription of the issue and abnormal return from new issue on the first trading day. They explained that oversubscription signals the higher demand of the issue. The higher demand leads to raised price of the issue on the first trading day. The study could not found significant relationship between degree underpricing of IPOs and other independent variables. An analysis by Sohail and Raheman (2009) also showed at $1 \%$ level of significance that there is a positive impact of oversubscription on the level underpricing. Beatty and Ritter (1986) also documented the positive association between rate of oversubscription and degree of underpricing.

Acqua, Etro, Teti, and Murri (2014) found positive relationship between retained ownership and degree of underpricing in Italy. Robinson, Robinson, and Peng (2004) explained, price of new issue tends to be higher when ownership retention of the issue is higher. They interpreted the cause-effect relationship by considering ownership retention as signal of their expectation about the future performance of the company. When owners expect higher future revenues from a company, they try to retain higher fraction of securities. Retained ownership is one way to signal private information to public. This phenomenon was described by Welch (1989).

Islam (1999) and Islam et al., (2010) provided evidence of high degree of IPO underpricing in Bangladesh. Islam (1999) found $116.01 \%$ average initial returns of IPOs considering 95 companies that went for IPOs during 1994-1999. Islam et al., (2010) studied 117 companies that were listed in the years 1995 to 2005. Out of 117 companies 102 companies were underpriced, 02 companies had similar pricing and 13 companies were underpriced. The mean level of underpricing of 117 companies was found as $156.16 \%$. They found positive effect of offer size and firm size on degree of underpricing. They recommended that the fixed price method of initial public offerings should be reviewed to diminish the degree of underpricing. They also emphasized on implementation of book -building method.

Bangladesh Securities and Exchange Commission has made reforms in public issue rules. It introduced Public Issue Rule, 2015 replacing Public Issue Rules, 2006. As per the new rule, companies are only allowed to offload share at par under fixed price method. No premium can be charged under this method. This study incorporated IPOs that came into market after implementation of the new rule. 


\section{Data and methodology}

\subsection{Data}

This study will conduct to examine new companies, which were listed in DSE for the period 2007 to 2016. Primarily, this study will try to find out the efficient model to predict the underpricing in the Bangladesh capital market. This study examines different factors which can predict the underpricing in Bangladesh capital market. Among different factors that have been discussed in the above discussion, issue price, issue size, market return, percentage of share issued to the public, oversubscription, age of the firm and size of the firm have been taken into consideration in this research.

The research has been conducted on 100 companies, selected from the 141 companies which were listed in Dhaka Stock exchange over the period 2007 to 2016 (Table I).

Table I: Summary of companies for the period 2007 to 2016

\begin{tabular}{lrrrrr}
\hline Year & No. of Total IPOs & No. of Selected & \multicolumn{3}{c}{ No. of IPOs that are not included in the study } \\
\cline { 4 - 6 } & issued & 10 & Mutual Fund & Bond & Other* \\
\hline 2007 & 12 & 8 & 1 & 1 & 0 \\
2008 & 10 & 11 & 2 & 0 & 0 \\
2009 & 15 & 7 & 3 & 0 & 1 \\
2010 & 21 & 5 & 12 & 1 & 1 \\
2011 & 13 & 9 & 6 & 1 & 1 \\
2012 & 14 & 14 & 4 & 0 & 1 \\
2013 & 17 & 17 & 2 & 0 & 1 \\
2014 & 17 & 12 & 1 & 0 & 0 \\
2015 & 14 & 7 & 2 & 0 & 1 \\
2016 & 10 & 100 & 33 & 3 & 1 \\
Total & 143 & \multicolumn{4}{c}{ IPOs } \\
\hline Note: * other segments include stocks that are directly listed in the exchange (not issuing new shares), pricing \\
through book building system (Laws regarding book building system has been changed several times. different \\
issues have been issued under different time period under different regulations of book building system), seasoned \\
public offering.
\end{tabular}

\subsection{Methodology}

From the above discussion, it is evident that there are lot of factors that affect the under pricing the initial public offerings. Lack of observable market price prior to the offering and market environment makes the IPO pricing difficult. For robustness of the study, econometric model has been used to observe the impact of several market and company specific variables. To formulate the functional model, mixed model has been used. Functional model is given below:

$$
\log (U N D)=\alpha_{0}+\beta_{1} \log \operatorname{Var}_{1}+\beta_{2} \operatorname{Var}_{2}+\beta_{3} \text { Dummy } \operatorname{Var}_{3} \ldots \ldots+\beta_{n} \operatorname{Var}_{n}+\varepsilon
$$

Previous studies used the initial return available after listing to measure the underpricing. Besides market adjusted initial return can also be used. In this study, both initial return and market adjusted initial return have been used to determine the underpricing. Underpricing of the stock has been calculated through initial return (IR) and market adjusted initial return (MAIR).

$$
I R_{i}=\ln \left(\frac{P_{i, t}}{E_{i}}\right)
$$

Where, IRi is the initial return, $\mathrm{Pi}, \mathrm{t}$ is the trading price of the share (i) at its first trading day on the secondary market and Ei is the issue price (E) of the share (i). 


$$
M A I R_{i}=\ln \left(\frac{P_{i, t}}{E_{i}}\right)-\ln \left(\frac{M_{t}}{M_{t, 0}}\right)
$$

Where, MAIRi is the market adjusted initial return, $\mathrm{Pi}$, $\mathrm{i}$ is the trading price of the share (i) at its first trading day on the secondary market and $E i$ is the issue price $(E)$ of the share (i). $M_{t}$ is the market index value (DSEX index of Dhaka Stock Exchange) in the first trading day of the share and $M_{t, o}$ is the market index value (DSEX index of Dhaka Stock Exchange) in the closing day of subscription period.

For robustness of the study, while performing multiple regression analysis, several variables are considered as predictor variable which effect the underpricing of the IPO stock in the listing day. In this study issue price (IP), issue size (IS), market return (MR), floated share (FF), oversubscription (OVS), premium (PR), age of the firm (AOF), size of the firm (SOF) are considered to examine the impact on underpricing of IPOs. To detect the fitted model eight predictors (independent variable) have been used in the study. In every model, predictor variable, one at a time, has been dropped from model to find the most fitted model.

Multicollinearity has been checked for every model of the study for finding the linear relation between two or more independent variables. Variance inflation factor (VIF) is used to measure the strength of the multicollinearity. A VIF near 1 indicates that multicollinearity is not a problem for the independent variable.

Table II: Summary of variables

\begin{tabular}{|c|c|c|c|}
\hline Variable & Measure & Explanation & Symbol \\
\hline $\begin{array}{l}\text { Initial } \quad \text { Return } \\
\text { (IR) }\end{array}$ & $\begin{array}{l}\text { Log return of the trading price of the } \\
\text { share at its first trading day on the } \\
\text { secondary market and the offer price. }\end{array}$ & Measuring the underpricing (UND). & $\mathrm{IR}$ \\
\hline $\begin{array}{l}\text { Market } \\
\text { Adjusted }\end{array}$ & $\begin{array}{l}\text { Log Initial return minus the Log } \\
\text { market return in the same period }\end{array}$ & Measuring the underpricing (UND). & MAIR \\
\hline $\begin{array}{l}\text { Excess Return } \\
\text { (MAIR) }\end{array}$ & & & \\
\hline Issue Price (IP) & $\begin{array}{l}\text { Final offer price by the issuer } \\
\text { including premium (if there is any } \\
\text { premium) }\end{array}$ & $\begin{array}{l}\text { Used as independent variable. Issue } \\
\text { price adjusted for face value } \\
\text { considering face value of } 10 \text { and } \\
\text { taking log transformation of the } \\
\text { variable. }\end{array}$ & LN(IP) \\
\hline Issue Size (IS) & $\begin{array}{l}\text { Issue price multiple by number of } \\
\text { share issued in initial public offering } \\
\text { (IPO) }\end{array}$ & $\begin{array}{l}\text { Used as independent variable. Total } \\
\text { amount that issuer company wants } \\
\text { to raise from the IPO. Taking log } \\
\text { transformation of the Variable. }\end{array}$ & LN(IS) \\
\hline $\begin{array}{l}\text { Floated Share } \\
\text { (FS) }\end{array}$ & $\begin{array}{l}\text { Number of share issued in the IPO } \\
\text { divided by Total number of shares of } \\
\text { the company after IPO. }\end{array}$ & $\begin{array}{l}\text { Used as independent variable. } \\
\text { Percentage of the equity share } \\
\text { offered to the public offering. }\end{array}$ & FS \\
\hline oversubscriptio & Amount of over subscription divided & Used as independent variable. & OVS \\
\hline n (OVS) & by IssI & $\begin{array}{l}\text { Number of times the IPO has been } \\
\text { subscribed over offer size in the } \\
\text { issue period. }\end{array}$ & \\
\hline Premium (PR) & $\begin{array}{l}\text { Difference between offer price and } \\
\text { face value. }\end{array}$ & $\begin{array}{l}\text { Used as independent variable. If } \\
\text { there is premium then it is } 1 \text { or } \\
\text { otherwise o (Dummy). }\end{array}$ & $D(P R)$ \\
\hline $\begin{array}{l}\text { Market Return } \\
(M R)\end{array}$ & $\begin{array}{l}\text { Log Market return in the period } \\
\text { between trading price of the share at } \\
\text { its first trading day on the secondary } \\
\text { market and the offer price }\end{array}$ & Used as independent variable. & MR \\
\hline
\end{tabular}


Age of the Firm Number of years from the date of Used as independent variable.

AOF (AOF) incorporation to the date of IPO.

Size of the Firm Total asset of the company at the Used as independent variable taking LN(SOF) (SOF) time of the issuance. log transformation of the variable.

\section{Research result and interpretation}

Table III identifies the basic underpricing of the IPOs for every single period along with the whole period from 2007 to 2016. For calculating underpricing, initial return (IR) and market adjusted initial return (MAIR) has been used. Highest degree of underpricing considering the initial return was identified in the year 2010 (IR of $558.41 \%$ with standard deviation of $377.90 \%$ and MAIR of $458.27 \%$ in 2009 with standard deviation of $307.13 \%$ ). For the total study period, average underpricing has been documented as initial return of $284 \%$ and market adjusted initial return of $266 \%$. Maximum level of underpricing expressed as initial return was $1531 \%$ (2012) and as market adjusted initial return was 1291.23\% (2009). Minimum level of underpricing with initial return was $-0.50 \%$ (Overpricing in 2012) and market adjusted initial return was $0.83 \%(2012)$.

Table III: IPOs underpricing statistics

\begin{tabular}{|c|c|c|c|c|c|c|}
\hline Year & No. of IPOs & Underpricing* & Mean & Standard dev & Min & Max \\
\hline \multirow[t]{2}{*}{2007} & 10 & IR & $198.84 \%$ & $133.81 \%$ & $24.00 \%$ & $466.17 \%$ \\
\hline & & MAIR & $158.41 \%$ & $119.89 \%$ & $2.38 \%$ & $404.17 \%$ \\
\hline \multirow[t]{2}{*}{2008} & 8 & IR & $268.33 \%$ & $285.67 \%$ & $48.75 \%$ & $779.25 \%$ \\
\hline & & MAIR & $261.75 \%$ & $258.75 \%$ & $56.88 \%$ & $705.90 \%$ \\
\hline \multirow[t]{2}{*}{2009} & 11 & IR & $458.41 \%$ & $407.63 \%$ & $81.75 \%$ & $1527.50 \%$ \\
\hline & & MAIR & $420.13 \%$ & $352.72 \%$ & $81.07 \%$ & $1291.23 \%$ \\
\hline \multirow[t]{2}{*}{2010} & 7 & IR & $558.74 \%$ & $377.90 \%$ & $135.75 \%$ & $1262.00 \%$ \\
\hline & & MAIR & $458.23 \%$ & $307.13 \%$ & $123.37 \%$ & $1002.50 \%$ \\
\hline \multirow[t]{2}{*}{2011} & 5 & IR & $287.99 \%$ & $299.46 \%$ & $21.33 \%$ & $640.00 \%$ \\
\hline & & MAIR & $332.74 \%$ & $331.01 \%$ & $40.88 \%$ & $696.12 \%$ \\
\hline \multirow[t]{2}{*}{2012} & 9 & IR & $255.85 \%$ & $489.30 \%$ & $-0.50 \%$ & $1531.00 \%$ \\
\hline & & MAIR & $229.00 \%$ & $395.95 \%$ & $0.83 \%$ & $1235.41 \%$ \\
\hline \multirow[t]{2}{*}{2013} & 14 & IR & $234.60 \%$ & $197.30 \%$ & $25.33 \%$ & $721.00 \%$ \\
\hline & & MAIR & $238.35 \%$ & $238.35 \%$ & $31.52 \%$ & $743.69 \%$ \\
\hline \multirow[t]{2}{*}{2014} & 17 & IR & $274.54 \%$ & $221.85 \%$ & $13.24 \%$ & $673.00 \%$ \\
\hline & & MAIR & $259.61 \%$ & $204.43 \%$ & $17.35 \%$ & $615.83 \%$ \\
\hline \multirow[t]{2}{*}{2015} & 12 & IR & $168.40 \%$ & $129.27 \%$ & $2.00 \%$ & $384.00 \%$ \\
\hline & & MAIR & $175.48 \%$ & $127.38 \%$ & $4.60 \%$ & $355.42 \%$ \\
\hline \multirow[t]{2}{*}{2016} & 7 & IR & $227.23 \%$ & $156.87 \%$ & $83.00 \%$ & $501.00 \%$ \\
\hline & & MAIR & $220.71 \%$ & $143.40 \%$ & $92.58 \%$ & $477.14 \%$ \\
\hline \multirow[t]{2}{*}{ Total } & 100 & IR & $284 \%$ & $290 \%$ & $-0.50 \%$ & $1531 \%$ \\
\hline & & MAIR & $266 \%$ & $254 \%$ & $0.83 \%$ & $1291.23 \%$ \\
\hline
\end{tabular}

Note: * Underpricing is measured through both Initial return (IR) and Market adjusted initial return (MAIR). IR is measured by taking the difference of the closing price at the listing date with the offering price and divided by the offer price of the stock. MAIR is measured by the difference between IR and Market Return on the period of subscription closing date and listing date.

\subsection{Modeling underpricing (Initial return)}

As a measure of underpricing, initial return (IR) is taken as dependent variable to run the multiple regressions. In every model, one predictor variable is dropped to find the fitted model. The multiple regression equation is given below:

$$
\begin{aligned}
& I R=\alpha_{0}+\beta_{1} \log I P+\beta_{2} \log I S+\beta_{3} F S+\beta_{4} O V S+\beta_{5} D(P S)+\beta_{6} \log M R+\beta_{7} A O F \\
& +\beta_{8} \log S O F
\end{aligned}
$$


Table IV summarizes STATA regression output result of multiple regression (OLS method) of all five models where initial return (IR) is used as dependent variable.

Table IV: Regression result of underpricing (IR) with other independent variables

\begin{tabular}{|c|c|c|c|c|c|c|}
\hline & & Model 1 & Model 2 & Model 3 & Model 4 & Model 5 \\
\hline \multirow[t]{2}{*}{ LN(IP) } & Coef. & -.381 & -.3810 & -.3816 & -.3956 & -.2383 \\
\hline & t-stat & $-2.53 * *$ & $-2.55^{* *}$ & $-2.56 * *$ & $-2.70 * * *$ & $-2.53^{* *}$ \\
\hline \multirow[t]{2}{*}{ LN(IS) } & Coef. & -.0457 & -.0461 & -.0471 & - & ---- \\
\hline & t-stat & -0.50 & -0.57 & -0.59 & ---- & ----- \\
\hline \multirow[t]{2}{*}{ FS } & Coef. & -.0017 & ----- & --- & --- & ---- \\
\hline & t-stat & -0.01 & --.-- & --.-- & - & --.-- \\
\hline \multirow[t]{2}{*}{ OVS } & Coef. & .0193 & .0193 & .0193 & .0202 & .0197 \\
\hline & t-stat & $6.35^{* * *}$ & $6.42^{* * *}$ & $6.45^{* * *}$ & $8.00 * * *$ & $7.84^{* * *}$ \\
\hline \multirow[t]{2}{*}{$D(P R)$} & Coef. & .2471 & .2465 & .2484 & .2377 & --- \\
\hline & t-stat & 1.34 & 1.43 & 1.45 & 1.40 & ---- \\
\hline \multirow[t]{2}{*}{$\mathrm{LN}(\mathrm{MR})$} & Coef. & 1.3803 & 1.3799 & 1.3750 & 1.4234 & 1.4260 \\
\hline & t-stat & $3.18 * * *$ & $3.20 * * *$ & $3.21 * * *$ & $3.40 * * *$ & $3.39 * * *$ \\
\hline \multirow[t]{2}{*}{ AOF } & Coef. & .0027 & .0007 & - & ---- & ---- \\
\hline & t-stat & 0.16 & 0.16 & --- & --- & ---- \\
\hline \multirow[t]{2}{*}{ LN(SOF) } & Coef. & .1012 & .1015 & .1030 & .0886 & .0912 \\
\hline & t-stat & $1.86^{*}$ & $2.18 * *$ & $2.27^{* *}$ & $2.33^{* *}$ & $2.39 * *$ \\
\hline Constant & Coef. & .2833 & .2844 & .2816 & -.3132 & -.6851 \\
\hline R-sqr & & 0.6007 & 0.6007 & 0.6006 & 0.5991 & 0.5908 \\
\hline Adj R-sqr & & 0.5656 & 0.5703 & 0.5748 & 0.5778 & 0.5736 \\
\hline F value & & $17.11 * * *$ & $19.77^{* * *}$ & $23 \cdot 31 * * *$ & $28.10 * * *$ & $34.29^{* * *}$ \\
\hline Mean VIF & & 2.93 & 2.65 & 2.89 & 2.44 & 1.41 \\
\hline
\end{tabular}

Note: *,** and $* * *$ means significance at $10 \%, 5 \%$ and $1 \%$ level. VIF means variance inflation factor. it is used to measure the multicollinearity. A VIF near 1 suggest that multicollinearity is not a problem for the independent variable.

Model 1: The F statistics (17.11) and its $p$ value clearly indicate the regression is significant. The t statistic for Market return, oversubscription and issue price are large with a relatively small $p$ value. The t statistics for issue size, floating share, age of the firm and premium is not significant provided that other predictor variables remain in the regression function. Among them $t$ statistics for floating share (FS) is the lowest. This suggests that the term $\beta_{3} x_{3}$ can be dropped from the regression function.

Model 2: After dropping the floating share from model 1, model 2 consists of seven predictor variables. The F statistics (19.77) is larger than model 1 (17.11) and its $p$ value clearly indicate the regression is significant. The R-square (60.07\%) remain same that justified the dropping of the age of the firm variable. In this model, the $t$ statistic for issue size, age of the firm and premium is not significant. Among them $t$ statistics for floating share is the lowest. This suggests that the age of the firm (AOF) can be dropped from the regression function.

Model 3: After dropping the age of the firm from model 2, model 3 consists of six predictor variables. The F statistics (23.31) is larger than model 2 (19.77) and its p value clearly indicate the regression is significant. The R-square (60.06\%) remains almost same that justified the dropping of the floating share variable. The issue size and premium remain insignificant in the model 3. Between them $t$ statistics for issue size is the lowest. This suggests that the issue size (IS) can be dropped from the regression function.

Model 4: After dropping the issue size from model 3, model 4 consists of five predictor variables. The $\mathrm{F}$ statistics (28.10) is larger than model 3 (23.31) and its p value clearly indicate the regression is significant. The R-square (59.91\%) remain almost same that justified the dropping of the issue size variable. Only the premium (PR) variable remains insignificant in the model 4 . This suggests that the premium variable can be dropped from the regression function. 
Model 5: After dropping the premium from model 4, model 5 consists of four predictor variables. The $\mathrm{F}$ statistics (34.29) is larger than model 4 (28.10) and its p value clearly indicate the regression is significant. The $t$ statistics for every predictor variable are statistically significant as well as mean VIF is near to 1.

Selected Model: Among five regression model, $\mathrm{t}$ statistic of every variable in model 5 is statistically significant. $R$ square of the model is $59.08 \%$ which is not significantly different from the other model. Among the five models, mean VIF of the regression is the lowest that indicate lowest correlation among the predictor variables. The selected model is-

$$
I R=-.6851-.2383 \log I P+.01970 V S+1.4260 \log M R+.0912 \log S O F
$$

\subsection{Modeling underpricing (Market adjusted Initial return)}

As a measure of underpricing, the study also considered market adjusted initial return (MAIR) as dependent variable to run the multiple regressions. In every model, one independent variable is dropped to find the fitted model. The multiple regression equation is given below:

$$
\begin{aligned}
& \text { MAIR }=\alpha_{0}+\beta_{1} \log I P+\beta_{2} \log I S+\beta_{3} F S+\beta_{4} O V S+\beta_{5} D(P S)+\beta_{6} \log M R+\beta_{7} A O F \\
& +\beta_{8} \log S O F
\end{aligned}
$$

Table V summarizes output of multiple regression (OLS method) run by using STATA where market

\begin{tabular}{|c|c|c|c|c|c|c|c|}
\hline & & Model 1 & Model 2 & Model 3 & Model 4 & Model 5 & Model 6 \\
\hline \multirow[t]{2}{*}{$\mathrm{LN}(\mathrm{IP})$} & Coef. & -.3810 & -.3810 & -.3816 & -.3956 & -.4186 & -.2609 \\
\hline & t-stat & $-2.53^{* *}$ & $-2.55^{* *}$ & $-2.56 * *$ & $-2.70 * * *$ & $-2.89 * * *$ & $2.85 * * *$ \\
\hline \multirow[t]{2}{*}{ LN(IS) } & Coef. & -.0457 & -.0461 & -.0471 & ---- & ---- & ---- \\
\hline & t-stat & -0.50 & -0.57 & -0.59 & ----- & ---- & --.-- \\
\hline \multirow[t]{2}{*}{ FS } & Coef. & -.0017 & - & ---- & --- & --- & - \\
\hline & t-stat & -0.01 & --.-- & --.-- & --.-- & ---- & --.-- \\
\hline \multirow[t]{2}{*}{ OVS } & Coef. & .0193 & .0193 & .0193 & .0202 & .0201 & .0196 \\
\hline & t-stat & $6.53^{* * *}$ & $6.42 * * *$ & $6.45 * * *$ & $8.00 * * *$ & $7.97 * * *$ & $7.82 * * *$ \\
\hline \multirow{2}{*}{$D(P R)$} & Coef. & .2471 & .2465 & .2484 & .2377 & .2384 & --.-- \\
\hline & t-stat & 1.34 & 1.43 & 1.45 & 1.40 & 1.40 & ---- \\
\hline \multirow[t]{2}{*}{$\mathrm{LN}(\mathrm{MR})$} & Coef. & .3803 & .3799 & .3750 & .4234 & --- & -.-- \\
\hline & t-stat & 0.87 & 0.88 & 0.88 & 1.01 & --- & - \\
\hline \multirow[t]{2}{*}{ AOF } & Coef. & .0007 & .0007 & - & ---- & ---- & ---- \\
\hline & t-stat & 0.16 & 0.16 & --.-- & --.-- & --_-- & --.-- \\
\hline \multirow[t]{2}{*}{ LN(SOF) } & Coef. & .1012 & .1015 & .1030 & .0886 & .0922 & .0948 \\
\hline & t-stat & $1.86^{*}$ & $2.18 * *$ & $2.27^{* *}$ & $2.33^{* *}$ & $2.44^{* *}$ & $2.50 * *$ \\
\hline Constant & Coef. & .2833 & .2844 & .2816 & -.3132 & -.3142 & -.6873 \\
\hline R-sqr & & 0.5644 & 0.5644 & 0.5643 & 0.5627 & 0.5579 & .5488 \\
\hline Adj R-sqr & & 0.5261 & 0.5313 & 0.5362 & 0.5394 & 0.5393 & .5347 \\
\hline F value & & $14.74^{* * *}$ & $17.03 * * *$ & $20.08 * * *$ & $24.19 * * *$ & $29.97^{* * *}$ & $38.92 * * *$ \\
\hline Mean VIF & & 2.93 & 2.65 & 2.89 & 2.44 & 2.75 & 1.49 \\
\hline
\end{tabular}
adjusted initial return (MAIR) is used as dependent variable.

Table V: Regression result of underpricing (MAIR) with other independent variables

Note: *, ** and $* * *$ means significance at $10 \%, 5 \%$ and $1 \%$ level. VIF means variance inflation factor. It is used to measure the multicollinearity. A VIF near 1 suggest that multicollinearity is not a problem for the independent variable.

Model 1: The F statistics (14.74) and its $\mathrm{p}$ value clearly indicate the regression is significant. The t statistic for issue price, oversubscription and size of the firm are large with a relatively small $p$ value. The $t$ statistics for issue size, floating share, market return, age of the firm and premium is not significant provided that other predictor variables remain in the regression function. Among them $t$ statistics for 
floating share (FS) is the lowest. This suggests that the term $\beta_{7} X_{7}$ can be dropped from the regression function.

Model 2: After dropping the floating share from model 1, model 2 consists of seven predictor variables. The F statistics (17.03) is larger than model 1 (14.74) and its $p$ value clearly indicate the regression is significant. The R-square (56.44\%) remain same that justified the dropping of the age of the firm variable. In this model, the $t$ statistic for issue size, floating share, market return and premium is not significant. Among them $t$ statistics for floating share is the lowest. This suggests that the age of the firm (AOF) can be dropped from the regression function.

Model 3: After dropping the age of the firm from model 2, model 3 consists of six predictor variables. The F statistics (20.08) is larger than model 2 (17.03) and its p value clearly indicate the regression is significant. The R-square (56.43\%) remain almost same that justified the dropping of the floating share variable. The issue size, market return and premium remain insignificant in the model 3 . Among them $t$ statistics for issue size is the lowest. This suggests that the Issue size (IS) can be dropped from the regression function.

Model 4: After dropping the issue size from model 3, model 4 consists of five predictor variables. The $\mathrm{F}$ statistics (24.19) is larger than model 3 (20.08) and its p value clearly indicate the regression is significant. The R-square (56.27\%) remain almost same that justified the dropping of the issue size variable. The market return and premium variable remains insignificant in the model 4 . This suggests that the premium (PR) variable can be dropped from the regression function.

Model 5: After dropping the premium from model 4, model 5 consists of four predictor variables. The $\mathrm{F}$ statistics (29.97) is larger than model 4 (24.19) and its p value clearly indicate the regression is significant. The R-square (55.79\%) decrease insignificantly that justified the dropping of the issue size variable. Only the market return variable remains insignificant in the model 4 . This suggests that the market return (MR) variable can be dropped from the regression function.

Model 6: After dropping the market return from model 5, model 6 is consists of three predictor variables. The F statistics (38.92) is larger than model 5 (29.97) and its p value clearly indicate the regression is significant. The $t$ statistics for every predictor variable are statistically significant as well as mean VIF is near to 1.

Selected Model: Among six regression models, t statistic of every variable in model 6 is statistically significant. $\mathrm{R}$ square of the model is $54.88 \%$ which is not significantly different from the other models. Among the six models, mean VIF of the regression is the lowest that indicate lowest correlation among the predictor variables. The selected model is-

$$
\text { MAIR }=-.6873-.2609 \log I P+.01960 V S+.0948 \log S O F
$$

\section{Conclusion}

This study investigates the underpricing and factor affecting the underpricing of initial public offering (IPOs). Out of 143 initial public offerings from 2007 to 2016, 100 IPOs have been selected for the study.

The study concludes that highest degree of underpricing has been observed in the year 2010 when overall market was in the bullish trend. And minimum level underpricing is observed in the year 2012 when the market was in the bearish trend. Average 284\% of underpricing (initial return) for the period 2007 to 2016 has been documented. On the other hand, $266 \%$ market adjusted initial return has been documented.

The study considers eight factors which are either company specific or issue specific to examine the effect of those factor on the underpricing. Underpricing has been calculated by both initial return (IR) and market adjusted initial return (MAIR). The predictor (independent) variable are issue price (IP),issue 
size (IS), market return (MR), floated share (FF), oversubscription (OVS), premium (PR) age of the firm (AOF), size of the firm (SOF). The study finds that issue price, oversubscription, market return and size of the firm got statistical significant impact on initial return (Underpricing). On the other analysis, issue price, oversubscription and size of the firm depict significant relationship with market adjusted initial return (Underpricing). From this it can be conclude that in Bangladesh issue price, oversubscription, market return and size of the firm has impact on underpricing.

This study does not address the deviations in the market environment, investor behavior, macroeconomic phenomena, shifting and implementation of Government and regulatory framework, sector of the company while formulating the model. In future, there is scope of further researches including the above issues to better scrutinize the reasons behind the IPO underpricing in Bangladesh.

\section{References}

Acqua, A. D., Etro, L. L., Teti, E., \& Murri, M. (2014). IPO underpricing and after market performance in Italy. International Journal of Finance and Banking , 1 (5), 30-45.

Bansal, R., \& Khanna, A. (2012). Determinants of IPOs initial return: extreme analysis of Indian market. Journal of Financial Risk Management , 1, 68-74.

Beatty, R. P., \& Ritter, J. R. (1986). Investment banking, reputation, and the underpricing of initial public offerings. Journal of Financial Economics 1, 15, 213-232.

Chan, K., Wang, J., \& Wei, K. J. (2004). Underpricing and long-term performance of IPOs in China. Journal of Corporate Finance , $409-430$.

Islam, M. A., Ali, R., \& Ahmad, Z. (2010). Underpricing of IPOs: the case of Bangladesh. Global Economy And Finance Journal , 3, 44-61.

Islam, M. S. (1999). The behavior of IPO underpricing in Bangladesh. Finance and Banking , 5, 87-109.

Kiymaz, H. (2000). The initial and aftermarket performance of IPOs in an emerging market: evidence from Istanbul stock exchange. Journal of Multinational Financial Management , 10 (2), 213-227.

Loughran, T., \& Ritter, J. (2004). Why has IPO underpricing changed over time? Financial Management ,537.

Robinson, R. M., Robinson, M. A., \& Peng, C. C. (2004). Underpricing and IPO ownership retention. Journal of Economics and Finance , 28 (1), 132-146.

Shah, S. N., \& Mehta, D. H. (2015). Initial performance of IPOs in India: EVIDENCE FROM 2010-2014. Samvad , 9, 77-86.

Sohail, M. K., \& Raheman, A. (2009). Determinants of underpricing of IPOs regarding financial \& nonfinancial firms in Pakistan. European Journal of Economics, Finance and Administrative Sciences (15), 62-73.

Titman, S., \& Wessels, R. (1988). The determinants of capital structure choice. The Journal of Finance , 43 (1), 1-19.

Welch, I. (1989). Seasoned offerings, imitation costs, and the underpricing of initial public offerings. The Journal of Finance , 44 (2), 421-449.

Yaakob, H., \& Halim, M. N. (2016). Initial public offering underpricing performance in Malaysia (listed on main market). International Journal of Scientific \& Engineering Research , 7 (12), 124-133. 